\title{
Discostella tatrica sp. nov. (Bacillariophyceae) - a small centric diatom from the Tatra Mountain lakes (Slovakia/Poland)
}

\author{
Lenka Procházková ${ }^{1 *}$, Václav Houk ${ }^{2} \&$ Linda NedBalová ${ }^{1,2}$ \\ ${ }^{1}$ Charles University, Faculty of Science, Department of Ecology, Viničná 7, CZ-128 44 Prague, Czech Republic; \\ * corresponding author e-mail: lenkacerven@gmail.com \\ ${ }^{2}$ Czech Academy of Sciences, Institute of Botany, Dukelská 135, CZ-379 82 Třeboň, Czech Republic
}

\begin{abstract}
A new small Discostella (Bacillariophyceae), D. tatrica ProchÁzková, Houk et Nedbalová sp. nov., from lakes of the High Tatra Mountains (Slovakia/Poland, Europe) is described here on the basis of light and electron microscopy. This species is reminiscent of D. guslyakowyi GenKal, BondarenKo et PopovsKaYa and D. stelligeroides (Hustedt) Houk et KLeE. However, it differs from D. guslyakowyi in having alveolae in the central parts, and from D. stelligeroides in the possibility of having an incomplete stellate pattern in its convex central parts and possessing an alveolus in its concave central parts. The valve morphology and ultrastructure is documented here in light and electron microscope images, and it is discussed, as well as its ecology, with these of other similar Discostella taxa.
\end{abstract}

Key words: diatoms, Discostella, morphology, taxonomy, ecology, phytoplankton, bottom sediments, mountain lakes

\section{Introduction}

The genus Discostella has been recently established by HouK \& KLEE (2004), and many diatom species formerly belonging to the genus Cyclotella have been transferred to this genus (Houk \& KLEE 2004; TujI \& WiLliams 2006). Subsequently, phylogenetic analyses of individual $18 \mathrm{~S}$ and partial 28S rDNA of Cyclotella sensu lato showed that these two genera are indeed genetically well-separated groups (JuNG et al. 2010). In this study, we describe a new small centric diatom species having marginal fultoportulae and a single rimoportula located between the costae and with a stellate pattern in the valve central part, and so belonging to the genus Discostella. It has recently been found in the plankton and bottom sediments of several mountain lakes in the High and the Western Tatras (Slovakia/Poland). This new taxon was first observed in bottom sediments of Nižné Temnosmrečinské and Vyšné Temnosmrečinské lakes taken in 1981 and 1983. Later, it was also found in plankton samples in these and other lakes of Tatras in 2004. The aim of this study is to describe the valve morphology and ultrastructure, together with the ecology, of this new small diatom species of the genus Discostella.

\section{Materials and Methods}

The Tatra mountain complex comprises the highest elevations of the Carpathian arc, and is situated along the Slovak-Polish border in Central Europe (20 $10^{\prime}$ E, $49^{\circ} 10^{\prime}$ N; Fig. 1). Although considerably smaller than the Alps, they have an alpine landscape as well as a high concentration of natural lakes: 138 major ones and 123 smaller (seasonal or $<0.01 \mathrm{ha}$ ), all of glacial origin. 89 lakes were sampled from the lake surface during a limnological survey in September 2004, with the new Discostella species found in 14 of these lakes (Table 1 and Table 2).

For the morphological study, the following samples were used:

1. Materialfrom thebottom sediments ofthelakes Nižné Temnosmrečinské and Vyšné Temnosmrečinské (High Tatras, Slovakia) collected by Dr. L. Kováčik (Department of Botany, Comenius University in Bratislava, Slovakia), July 7, 1981 and July 10, 1983.

2. Plankton samples from the lake Nižné Temnosmrečinské (High Tatras, Slovakia) collected by Dr. D. Hardekopf, Ph.D., September 24, 2004.

3. Plankton samples from the lake Wielki Staw Polski (High Tatras, Poland) collected by Dr. V. Sacherová, Ph.D., September 28, 2004.

4. Plankton samples from the lake Przedni Staw Polski (High Tatras, Poland) collected by Dr. V. Sacherová, Ph.D., September 28, 2004. 
Bottom sediment samples were fixed with $2 \%$ formaldehyde, plankton samples were preserved immediately by acid Lugol's solution. They were washed in distilled water and cleaned using hydrogen peroxide/potassium bichromate (see KRAMMER \& LANGE-Bertalot 1986). Bottom sediment subsamples of cleaned material were mounted in Pleurax for light microscopy (LM), or dried on aluminium stubs and coated with gold/palladium for scanning electron microscopy (SEM) using a TESLA BS-300 microscope. Cleaned planktonic material was dried on aluminium stubs and coated with gold for SEM on a JEOL 6380 LV. Several plankton subsamples were dried onto formwar-coated copper grids and examined with a JEOL 1011 transmission electron microscope (TEM).

To quantify the abundance and biovolume of phytoplankton taxa, plankton samples preserved with Lugol's solution were concentrated to 0.1 or 0.05 of the original volume. Counting and measuring were carried out in sedimentation chambers according to UTERMÖHL (1931). The biovolume of each taxon was calculated by approximating the cell shape to simple geometrical solids (HiLDEBRANDT et al. 1999) and expressed as $\mathrm{mm}^{3} \cdot \mathrm{l}^{-3}$ (STRAŠKRABOVÁ et al. 1999).

Multivariate analysis was performed using CANOCO 4.0 (TER BraAK \& ŠMilauer 1998). Analysis was restricted to those diatom taxa occurring in at least $5 \%$ of lakes or to diatom taxa contributing at least $5 \%$ to the total phytoplankton biomass of a lake. Furthermore, only lakes with these diatom taxa were included in the analysis, i.e. 45 of 89 lakes. The ordination was improved by excluding highly

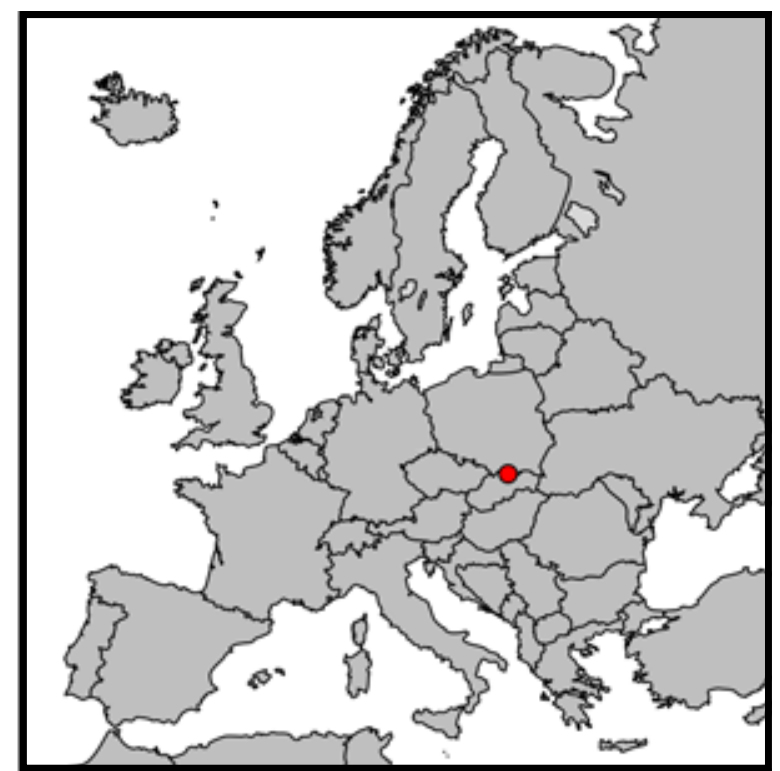

Fig. 1. Studied area: Tatra Mountains, Slovakia/Poland (black-red circle).

correlated variables (e.g. $\mathrm{Na}, \mathrm{Cl}, \mathrm{pH}, \mathrm{Ca}^{2+}, \mathrm{Mg}^{2+}$ ). Except for a dummy variable, all environmental and species data were logarithmically transformed, e.g. $\mathrm{Y}^{\prime}=\log \left(10^{*} \mathrm{Y}+1\right)$. Redundancy analysis (RDA) with stepwise variable selection based on the Monte Carlo permutation test $(1000$, accepted $\mathrm{p}<0.05)$ was performed to explore the distribution and biomass of different diatom species in relation to the measured environmental variables.

Physico-chemical data of the Tatra Mountain lakes were published by KoPÁČEK et al. (2006); several

Table 1. GPS coordinates of Tatra Mountain lakes where Discostella tatrica was recorded [(H) High Tatras; (W) Western Tatras].

\begin{tabular}{|c|c|c|c|}
\hline Lake code & Lake name & GPS coordinates & Tatras \\
\hline GA-1 & Zmarzly Staw Gąsienicowy & $49^{\circ} 13^{\prime} 26.69^{\prime \prime}, 20^{\circ} 1^{\prime} 20.44^{\prime \prime}$ & $\mathrm{H}$ \\
\hline $\mathrm{JA}-3$ & Malé Žabie javorové pl. & $49^{\circ} 12^{\prime} 8.80^{\prime \prime}, 20^{\circ} 8^{\prime} 57.56^{\prime \prime}$ & $\mathrm{H}$ \\
\hline MO-1 & Czarny Staw pod Rysami & $49^{\circ} 11^{\prime} 20.01^{\prime c}, 20^{\circ} 4^{\prime} 31.46^{\prime c}$ & $\mathrm{H}$ \\
\hline MS-4 & Vel’ké spišské pl. & $49^{\circ} 11^{\prime} 34.49^{\prime \prime}, 20^{\circ} 11^{\prime} 41.35^{\prime \prime}$ & $\mathrm{H}$ \\
\hline PS-3 & Wielki Staw Polski & $49^{\circ} 12^{\prime} 30.98^{\prime \prime}, 20^{\circ} 2^{\prime} 21.22^{\prime \prime}$ & $\mathrm{H}$ \\
\hline PS-5 & Przedni Staw Polski & $49^{\circ} 12^{\prime} 43.79^{\prime \prime}, 20^{\circ} 2^{\prime} 56.14^{\prime \prime}$ & $\mathrm{H}$ \\
\hline $\mathrm{RA}-1$ & Vyšné Račkove pl. & $49^{\circ} 11^{\circ} 58.77^{\prime}, 19^{\circ} 48^{\prime} 16.83^{\prime c}$ & $\mathrm{~W}$ \\
\hline RO-2 & Tretie Roháčske pl. & $49^{\circ} 12^{\prime} 31.50^{\circ}, 19^{\circ} 44^{\circ} 13.57^{،}$ & $\mathrm{~W}$ \\
\hline $\mathrm{RO}-4$ & Prvé Roháčske pl. & $49^{\circ} 12^{`} 23.45^{\prime}, 19^{\circ} 44^{\prime} 37.68^{\prime \prime}$ & W \\
\hline $\mathrm{SK}-1$ & Skalnaté pl. & $49^{\circ} 11^{`} 19.14^{\prime \prime}, 20^{\circ} 13^{\prime} 55.64^{\prime \prime}$ & $\mathrm{H}$ \\
\hline TE-1 & Vyšné Temnosmrečinské pl. & $49^{\circ} 11^{`} 19.51^{\prime}, 20^{\circ} 2^{\prime} 16.80^{\circ}$ & $\mathrm{H}$ \\
\hline TE-3 & Nižné Temnosmrečinské pl. & $49^{\circ} 11^{\prime} 33.33^{\prime \prime}, 20^{\circ} 1^{\prime} 46.24^{\prime \prime}$ & $\mathrm{H}$ \\
\hline VS-4 & Ladové pl. & $49^{\circ} 11^{\prime} 2.32^{\prime \prime}, 20^{\circ} 9^{\prime} 40.80^{\prime \prime}$ & $\mathrm{H}$ \\
\hline $\mathrm{ZL}-5$ & L'adové pl. v Zlomiskách & $49^{\circ} 9^{`} 47.58^{،}, 20^{\circ} 6^{\circ} 22.87^{\circ}$ & $\mathrm{H}$ \\
\hline
\end{tabular}


Table 2. Distribution, relative abundance and biomass of Discostella tatrica in plankton and total phytoplankton biomass and abundance of the Tatra Mountain lakes (September 2004) [(pl.) pleso; (Total PA) total phytoplankton abundance; (Total PB) total phytoplankton biovolume; (D. tatrica) Discostella tatrica. Lake codes are according Kopáček et al. (2006)].

\begin{tabular}{llllll}
\hline Lake code & Lake name & $\begin{array}{l}\text { Total PA } \\
(\text { cell.ml }\end{array}$ & $\begin{array}{l}\text { Abundance } \\
(\%)\end{array}$ & $\begin{array}{l}\text { Total PB } \\
\left(\mathrm{mm}^{3} .1^{-1}\right)\end{array}$ & $\begin{array}{l}\text { Biovolume } \\
(\%)\end{array}$ \\
\hline GA-1 & Zmarzly Staw Gąsienicowy & 75 & $<1$ & 0.01 & $<1$ \\
JA-3 & Malé Žabie javorové pl. & 1175 & 67 & 0.12 & 48 \\
MO-1 & Czarny Staw pod Rysami & 128 & $<1$ & 0.05 & $<1$ \\
MS-4 & Vel'ké spišské pl. & 993 & $<1$ & 0.24 & $<1$ \\
PS-3 & Wielki Staw Polski & 279 & $<1$ & 0.05 & $<1$ \\
PS-5 & Przedni Staw Polski & 5117 & 73 & 0.82 & 34 \\
RA-1 & Vyšné Račkove pl. & 403 & 32 & 0.17 & 6 \\
RO-2 & Tretie Roháčske pl. & 1355 & 65 & 0.11 & 43 \\
RO-4 & Prvé Roháčske pl. & 1056 & 64 & 0.10 & 55 \\
SK-1 & Skalnaté pl. & 268 & $<1$ & 0.002 & 7 \\
TE-1 & Vyšné Temnosmrečinské pl. & 589 & 3 & 0.09 & 1 \\
TE-3 & Nižné Temnosmrečinské pl. & 1089 & 10 & 0.24 & 3 \\
VS-4 & Ladové pl. & 635 & $<1$ & 0.14 & $<1$ \\
ZL-5 & Ladové pl. v Zlomiskách & 856 & $<1$ & 0.13 & $<1$ \\
\hline
\end{tabular}

physico-chemical parameters from the type locality are given in Table 3.

\section{Results}

Discostella tatrica Procházková, Houk et Nedbalová sp. nov. (Figs 2-36)

Diagnosis: Cellulae cylindricae, interdum in catenis brevibus. Frustula partim heterovalvata. Valvae circulares, 3.5-8.5 $\mu \mathrm{m}$ in diametro. Areae centrales leviter convexae vel concavae, heae convexae cum puncto distincto centrali, punctis (alveolis) satis grossis radialiter diospositis circumcincto, illae concavae cum ordinatione stellata haud distincta, ex striis radiantibus obscuris seu cum uno usque aliquot punctis (alveolis) in centro. Pars marginalis cum striis (alveolis) grossis radialiter ordinatis inaequaliter longis, $14.5-18$ in 10 $\mu \mathrm{m}$. Fultoportulae marginales interne visae inter 5-8 costis prope marginem positae, cum 2 poris satellitis, externe visae ad instar tuborum brevium. Rimoprtula unica in margine limbi inter duas fultoportulas.

Description: Cells cylindrical, sometimes in short chains, frustules can be heterovalvate. Valves circular, 3.5-8.5 $\mu \mathrm{m}$ in diameter. The central area is slightly convex or concave. The convex central areas have a stellate pattern consisting of radially arranged coarser puncta (alveoli), one distinct punctum is present in the hyaline valve centre. The concave central areas have an ill-defined stellate pattern consisting of radially arranged 'ghost' striae, or one to several coarser puncta (alveoli) in the valve centre. The marginal valve part consists of radially arranged coarse striae (alveoli) of unequal lengths, $14.5-18$ striae in $10 \mu \mathrm{m}$. The marginal fultoportulae are situated internally between 5-8 costae near the valve margin, with two laterally arranged satellite pori. Externally, there are short tubes. A single rimoportula is inserted at the valve edge between two marginal fultoportulae.

Holotype: Slide ZU7/93, Diatom Collection of Friedrich Hustedt, Alfred-Wegener-Institut für Polar- und Meeresforschung, Bremerhaven, Germany.

Material to holotype: R 1005, Diatom Collection of Friedrich Hustedt, Alfred-Wegener-Institut für Polar- und Meeresforschung, Bremerhaven, Germany.

Isotype: Slide no. D501, Diatom Slides Collection, Department of Botany, Charles University, Prague, Czech Republic.

Type locality: Mountain freshwater lake Nižné Temnosmrečinské pleso (High Tatras, Slovakia), leg. Dr. L'. Kováčik, July 10, 1981.

Etymology: The epithet tatrica is based on the name of the geographic region, the Tatra Mountains, where it was found.

\section{LM observations (Figs 2-15)}

In the examined holotype slide ZU7/93, the cells occur solitarily (Figs 7-15). In the plankton 
Table 3. Some physico-chemical parameters of the type locality lakes (the first three parameters are from PACL (1973), the others from the year 1981 were kindly given by Dr. L. Kováčik, Faculty of Natural Sciences, Comenius University in Bratislava, SK).

Temnosmrečinské lakes

\begin{tabular}{llll} 
& Vyšné & Nižné & Unit \\
\hline altitude & 1716 & 1674 & $\mathrm{~m} \mathrm{a.s.1.}$ \\
surface area & 0.055 & 0.12 & $\mathrm{~km}^{-2}$ \\
maximal depth & 20.0 & 37.8 & $\mathrm{~m}$ \\
temperature & 6.1 & 8.2 & ${ }^{\circ} \mathrm{C}$ \\
$\mathrm{pH}$ & 7.1 & 6.9 & \\
conductivity & 42 & 43 & $\mu \mathrm{S} . \mathrm{cm}^{-1}$ \\
alkalinity & 0.22 & 0.2 & $\mathrm{mekv} 1^{-1}$ \\
$\mathrm{P}_{\text {tot }}$ & 0.009 & 0.019 & $\mathrm{mg} .1^{-1}$ \\
$\mathrm{NO}_{3}-\mathrm{N}$ & 0.14 & 0.11 & $\mathrm{mg} .1^{-1}$ \\
$\mathrm{Cl}^{-}$ & 0,33 & 0.35 & $\mathrm{mg} .1^{-1}$ \\
$\mathrm{SO}_{4}^{2-}$ & 3.2 & 3.3 & $\mathrm{mg} .1^{-1}$ \\
$\mathrm{Na}^{+}$ & 0.29 & 0.31 & $\mathrm{mg} .1^{-1}$ \\
$\mathrm{~K}^{+}$ & 0.16 & 0.18 & $\mathrm{mg} .1^{-1}$ \\
$\mathrm{Ca}^{2+}$ & 7.16 & 7.16 & $\mathrm{mg} .1^{-1}$ \\
$\mathrm{Mg}^{2+}$ & 0.98 & 0.98 & $\mathrm{mg} .1^{-1}$ \\
\hline
\end{tabular}

samples from the majority of lakes, solitary cells and short chains consisting of $2-8$ cells (Figs 2-6) were found; chains consisting of two cells prevailed. Cells are shallow cylinders, with the pervalvar axis much shorter than the valve diameter (Figs 2-6). Valves were circular, with a diameter from 3.5-8.5 $\mu \mathrm{m}$. The central area occupies $2 / 5$ to $1 / 2$ of the valve diameter, with an ill-defined stellate pattern consisting of radially arranged ghost striae (Fig. 7), or with one to several coarse puncta in the valve centre (Figs 8-10) often creating an incomplete (Figs 11,12) or complete stellate pattern (Figs 13-15) consisting of more or less elongated drop-like puncta, 3-8 puncta in a ring. The central areas of sibling pairs are slightly convex or concave (Fig. 4). The marginal zone is radially striated with $14.5-18$ coarse striae in $10 \mu \mathrm{m}$, sharply separated from the central area. Between longer striae, short striae can be inserted at the valve margin. The marginal fultoportulae and the rimoportula are not distinguishable in LM. Initial cells/valves were not observed.

\section{SEM and TEM observations (Figs 16-36)}

Bottom sediment material from the lake Nižné Temnosmrečinské pleso (High Tatras, Slovakia) and plankton samples from the lakes Nižné Temnosmrečinské (High Tatras, Slovakia), Wielki Staw Polski and Przedni Staw Polski (High Tatras, Poland) were investigated in TEM (Figs 19-22) and SEM (Figs 16-18, 23-36). Initial cells/valves were not observed.

Valve exterior. The convex valve centre has a small, low spherical cap elevation; the surface is often uneven (Figs 23, 25, 26). The concave valve centre has a small, spherical cap depression; the surface is uneven (Figs 18,27) or has a pattern consisting of radially arranged low ribs with a small bulge in the centre (Fig. 24).

The marginal area of both convex and concave valves is composed of radially arranged ribs; between long ribs, shorter ribs can be inserted near the valve margin (Figs 27-36). The marginal area in the valves with the convex central part slopes down towards the centre (Fig. 23), whilst in the valves with the concave central part it slopes down towards the margin (Fig. 24). The marginal fultoportulae with short external tubular projections (see e.g. Figs 24-26) are located on the valve face/valve mantle junction. We were not able to distinguish the outer opening of the rimoportula.

Valve interior. The internal structure of the convex central parts is composed of opened, more or less elongated drop-like alveoli, bordered internally with coarser pori, with smaller pori inside (Figs 20-22, 30). They create a complete (Figs 22, 29, 30 ) or an incomplete (Figs 20, 21, 27, 28, 31-33) stellate pattern. The concave central areas are mostly smooth (Fig. 36), or they can have one alveolus near the centre (Figs 19, 34, 35). The marginal fultoportulae with two satellite pores positioned laterally are situated between costae near the valve margin (Figs 19-21, 28-36). A single rimoportula with a short sessile labium occurs at the valve edge between two costae (Figs 19-22, 28-34, 36).

\section{Distribution}

The most common pelagic diatom in this lake district was Fragilaria tenera (W. SMITH) LANGEBertalot, followed by Tabellaria flocculosa (Rотн) KütZING, which were present in 35 and 25 lakes, respectively. Other diatom species inhabiting the pelagial of Tatra Mountain lakes were, e.g. Cyclotella radiosa (GRunow) 

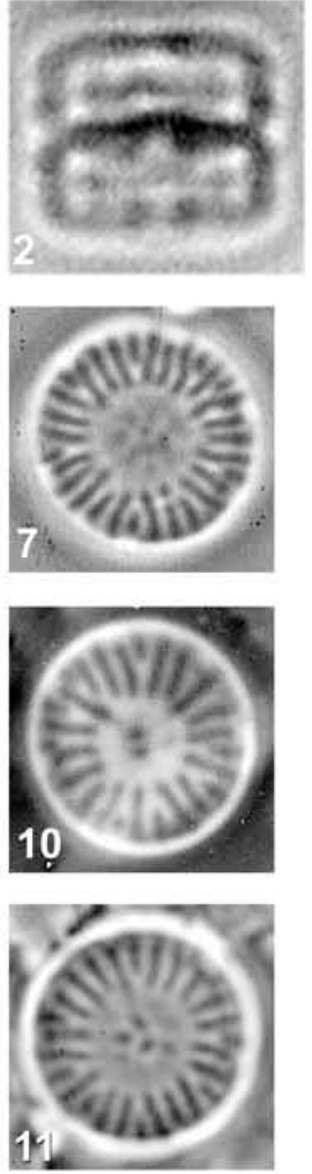
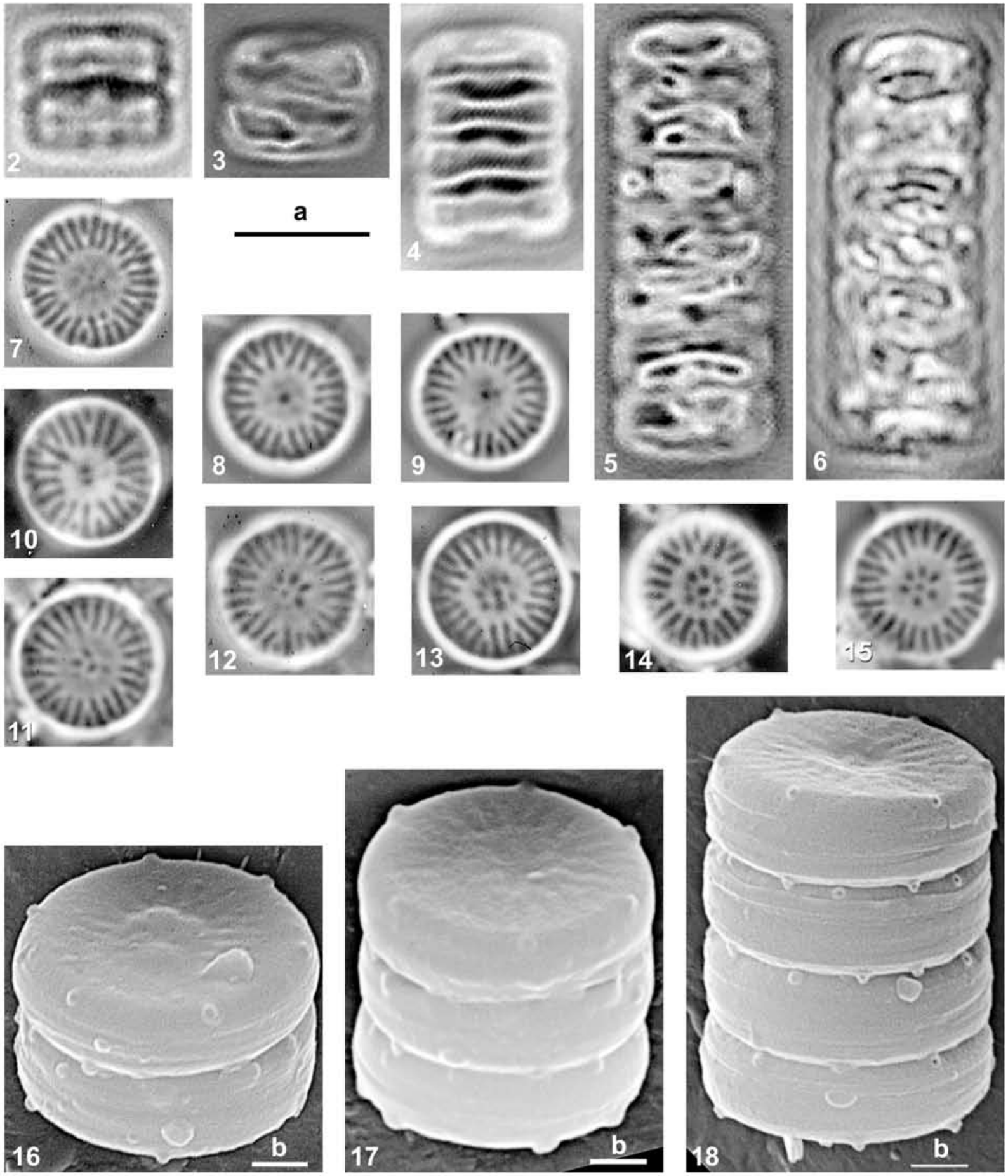

18

Figs 2-18. Discostella tatrica sp. nov.: (2-15) LM; (16-18) SEM; (2, 6, 16-18) Lake Przedni Staw Polski, plankton, leg. V. Sacherová; (3-5) Lake Nižné Temnosmrečinské, plankton, leg. D. Hardekopf; (7-15) holotype slide ZU7/93 „Lake Nižné Temnosmrečinské,“ Hustedt Coll., Bremerhaven (Germany). (2-6) girdle views of short chains composed of 2, 4 or 8 living cells. (7-15) valve views: (7) a valve with a ghost stellate pattern in the central part; (8-10) valves with 1 or 2 central puncta (alveoli); $(11,12)$ valves with an incomplete stellate pattern in the central part; $(13-15)$ valves with a complete stellate pattern in the central part. (16-18) short chains of frustules in SEM. Scale bar a $5 \mu \mathrm{m}$ (Figs 2-15); b $1 \mu \mathrm{m}$ (Figs 16-18). 

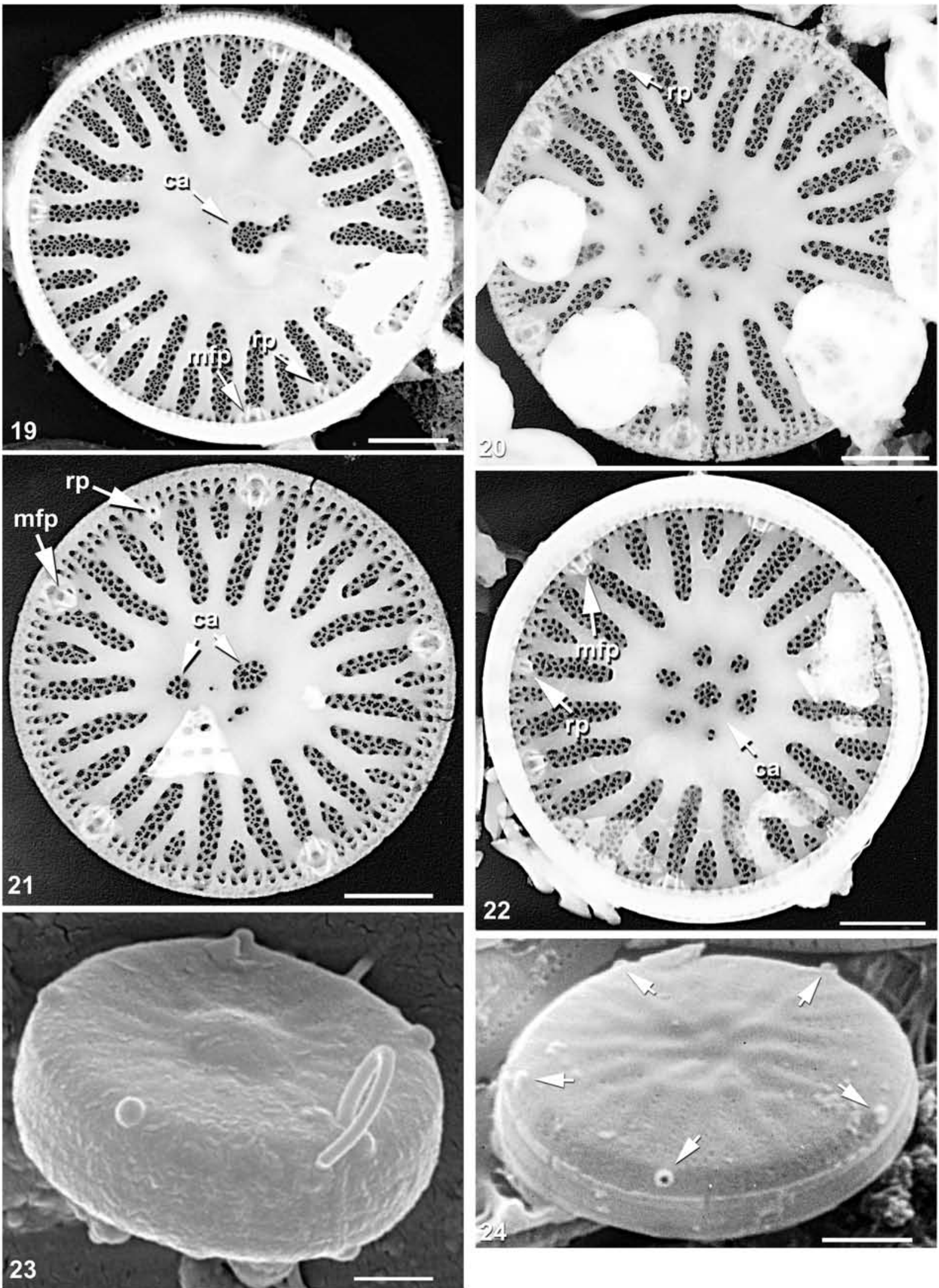

Figs 19-24. Discostella tatrica sp. nov.: (19-22) TEM. (19, 20) Lake Nižné Temnosmrečinské, plankton, leg. D. Hardekopf; $(21,22)$ Lake Wielki Staw Polski, plankton, leg. V. Sacherová. $(23,24)$ SEM. (23) Lake Przedni Staw Polski, plankton, leg. V. Sacherová; (24) type material R 1005 „Lake Nižné Temnosmrečinské,“ Hustedt Coll., Bremerhaven (Germany). (19-22) valve views; see the perforated cell walls inside the alveoli; (19) $\mathrm{mfp}=$ marginal fultoportula, rp=rimoportula, ca=central alveolus; (20) valve with incomplete stellate pattern in the central part; $\mathrm{rp}=$ rimoportula. (21) valve with two central part alveoli; $\mathrm{mfp}=\mathrm{marginal}$ fultoportula, $\mathrm{rp}=$ rimoportula, ca=central alveoli; (22) valve with complete stellate pattern in the central part; $\mathrm{mfp}=$ marginal fultoportula, rp=rimoportula. (23) tilted frustule with a small convex central part. (24) tilted frustule with a small concave central part; note low, radially arranged ribs in the marginal part and a small hump in the valve center. Scale bar $1 \mu \mathrm{m}$. 

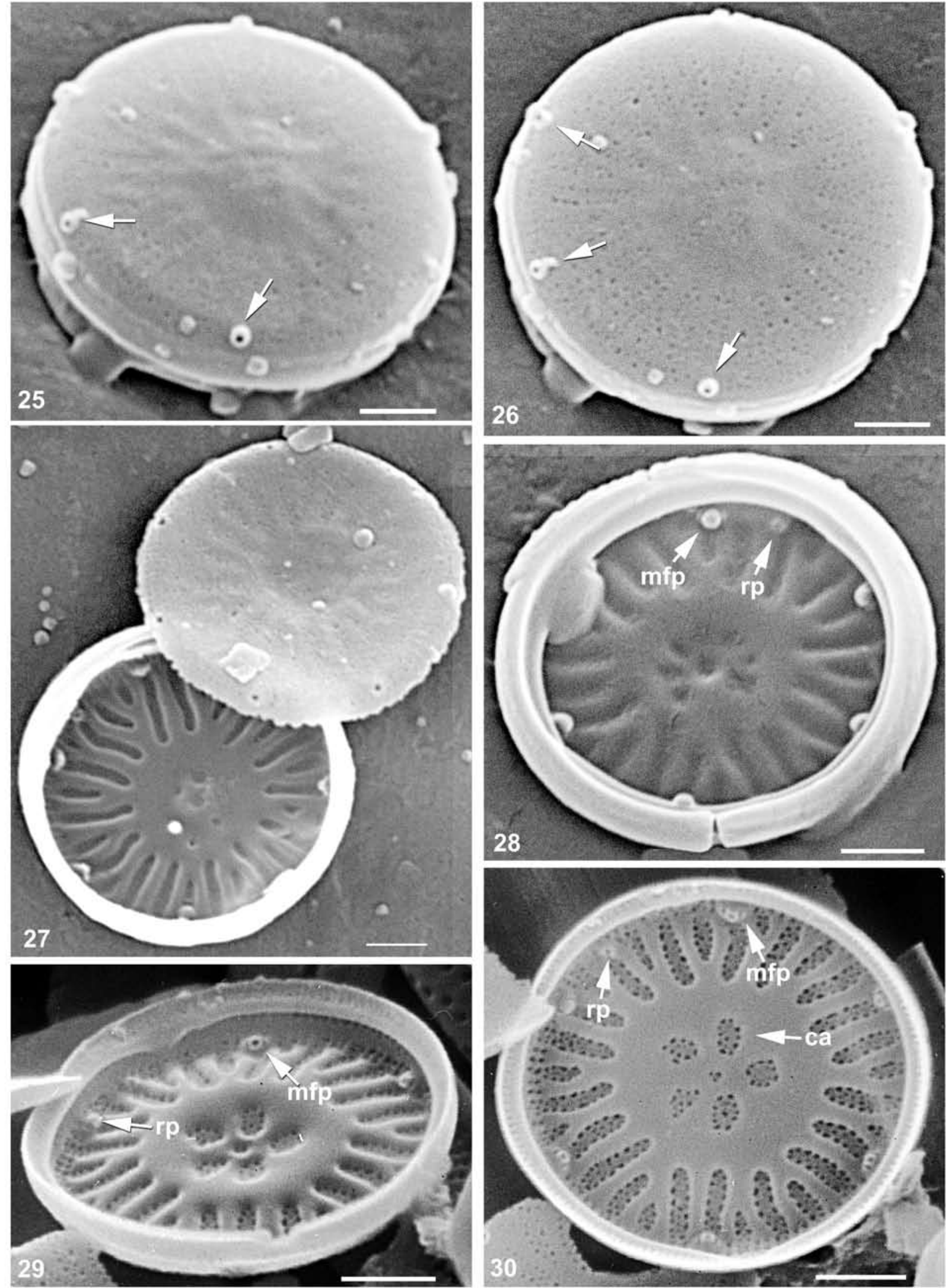

Figs 25-30. Discostella tatrica sp. nov. SEM: (25-28) Lake Przedni Staw Polski, plankton, leg. V. Sacherová. (29, 30) type material R 1005 „Lake Nižné Temnosmrečinské,“ Hustedt Coll., Bremerhaven (Germany). $(25,26)$ tilted frustules with convex central valve parts; note short external tubular projections of the marginal fultoportulae. (27) internal view of the valve without alveoli in the valve centre, partially overlaid with a valve with a small concave central part. (28) valve interior of a valve with an incomplete stellate pattern in the valve central part; $\mathrm{mfp}=$ marginal fultoportula, $\mathrm{rp}=$ rimoportula. $(29,30)$ internal view of the valve with a complete stellate pattern in the valve central part; (29) tilted valve; $\mathrm{mfp}=$ marginal fultoportula, rp=rimoportula; (30) valve front view; $\mathrm{mfp}=$ marginal fultoportula, $\mathrm{rp}=$ rimoportula, ca=central alveoli. Scale bar $1 \mu \mathrm{m}$. 

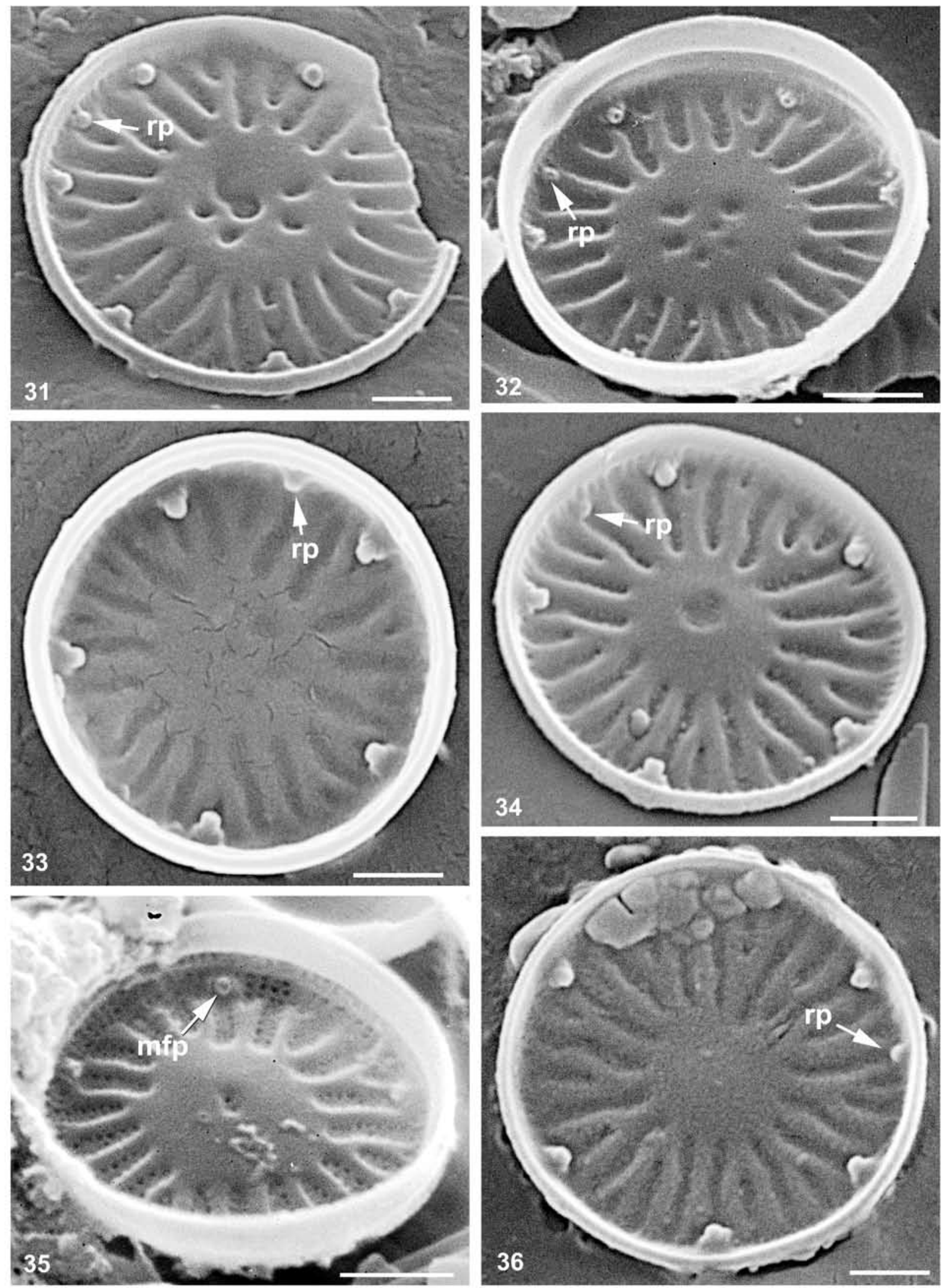

Figs 31-36. Discostella tatrica sp. nov. SEM: $(31,33,34,36)$ Lake Przedni Staw Polski, plankton, leg. V. Sacherová; $(32,35)$ Type material R 1005 „Lake Nižné Temnosmrečinské,“ Hustedt Coll., Bremerhaven (Germany).

Figs 31-36. Valve internal views: (31-33) valve with an incomplete stellate pattern in the central parts; rp=rimoportula; (34, 35) valves with one central alveolus; (34) rp=rimoportula; (35) $\mathrm{mfp}=$ marginal fultoportula; (36) valve with smooth central part; $\mathrm{rp}=$ rimoportula. Scale bar $1 \mu \mathrm{m}$. 


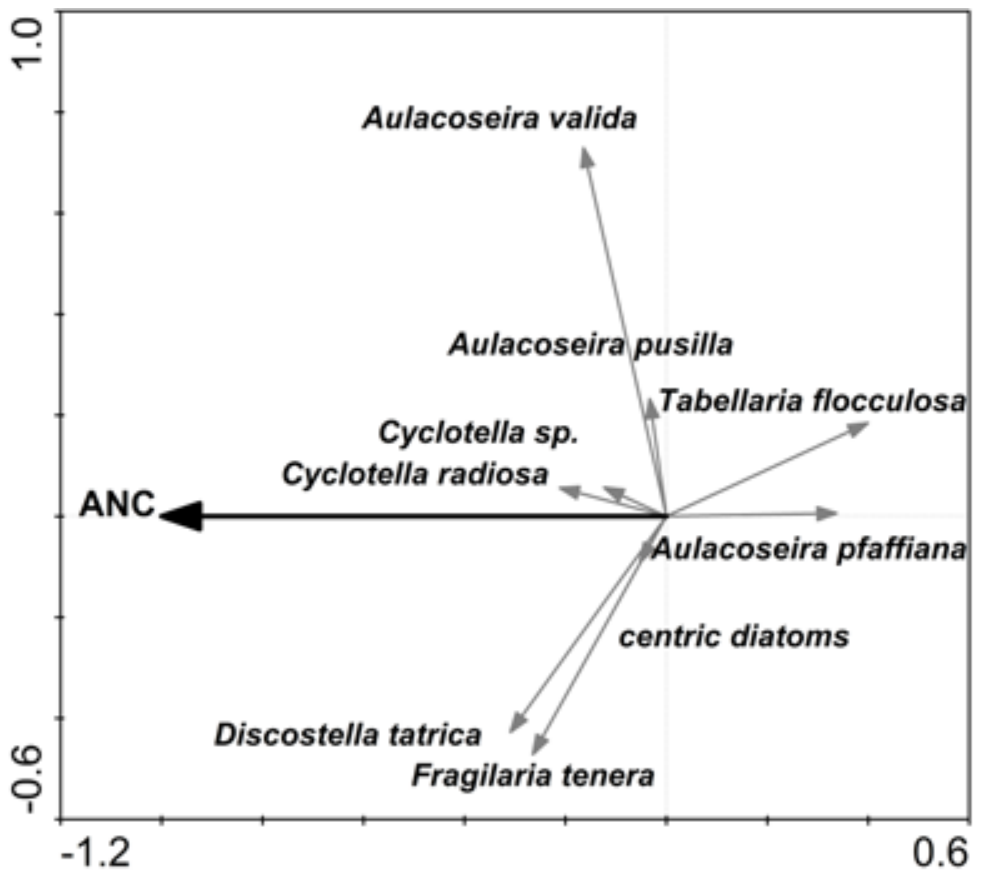

Fig. 37. RDA ordination of planktonic diatoms in relation to the significant $(\mathrm{p}=0.02)$ environmental variable (variance $5.6 \%$ ); (ANC) acid neutralising capacity.
Lemmermann, Aulacoseira alpigena (Grunow) Krammer, Aulacoseira pfaffiana (ReInsch) Krammer, Aulacoseira pusilla (MeISTER) Tus et Houki, Aulacoseira valida (GRUNow) Krammer, Tabellaria flocculosa and Tabellaria fenestrata (LyngBYe) KütZING. Discostella tatrica is a relatively widespread diatom of these lakes, with spatial distribution from the west (Roháčske Lake) to the east (Skalnaté Lake), and found in 14 of 89 lakes situated at 1562-2027 m a.s.l. (see Table 1 and Table 2). Discostella tatrica was often accompanied by populations of Fragilaria tenera and planktonic algae from different taxonomic groups, such as Dinophyta (Gymnodinium spp. $<12 \mu \mathrm{m}$ length; Gymnodinium helveticum PETARD), Cryptophyta (Cryptomonas erosa EhrenBerg, Cryptomonas marssonii SKUJA, Plagioselmis lacustris (PASCHER et RUtTNER) JAVORNICKÝ or/and ChrysophytaMallomonas crassisquama Asmund (FoTT).

\section{Abundance and biomass}

Bacillariophyta comprised the majority of the phytoplankton biomass in only six Tatra mountain lakes, and Discostella tatrica dominated in three of them, while other diatom species had relatively low biomass in most cases. The highest abundance as well as biomass of Discostella tatrica was found in Przedni Staw Polski Lake ( $3710 \pm 196$ cells. ml ${ }^{-1}$; $0.28 \pm 0.01 \mathrm{~mm}^{3} .1^{-1}$ ). In relative abundance and biomass, Discostella tatrica was also important in Prvé Roháčske Lake, Tretie Roháčske Lake and in
Malé Žabie javorové Lake (Table 2).

Redundancy analysis of diatom biomass composition and environmental variables relation showed that the distribution of Discostella tatrica reflected current chemistry, preferring lakes with higher values of acid neutralising capacity

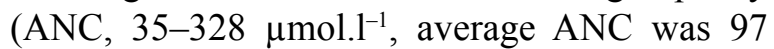
$\mu$ mol. $\left.1^{-1}\right)$. ANC was the only environmental variable significantly influencing diatom species composition and biomass, explaining 5.5\% of the variability $(p=0.02)$ (Fig. 37). Other planktic diatoms in non-acidic water were either restricted to a small number of lakes (Cyclotella radiosa in Vel'ké Bystré Lake, Cyclotella sp. in Malé Hincovo Lake, Aulacoseira alpigena in e.g. Vyšné Furkotské Lake), or occurred in a higher number of lakes $(>3)$ but dominated in only one of them (Aulacoseira pusilla in Morskie Oko, Aulacoseira valida in Nižné Jamnícke Lake and Fragilaria tenera in Zielony Staw Gąsienicowy Lake). On the other hand, Aulacoseira pfaffiana and Tabellaria flocculosa preferred acid lakes (Fig. 37).

\section{Discussion}

The most similar taxa to $D$. tatrica, from the point of view of valve morphology, are D. guslyakovyi and $D$. stelligeroides. These two taxa share several features with $D$. tatrica, such as small valve size and similar distribution of the marginal fortuportula. 


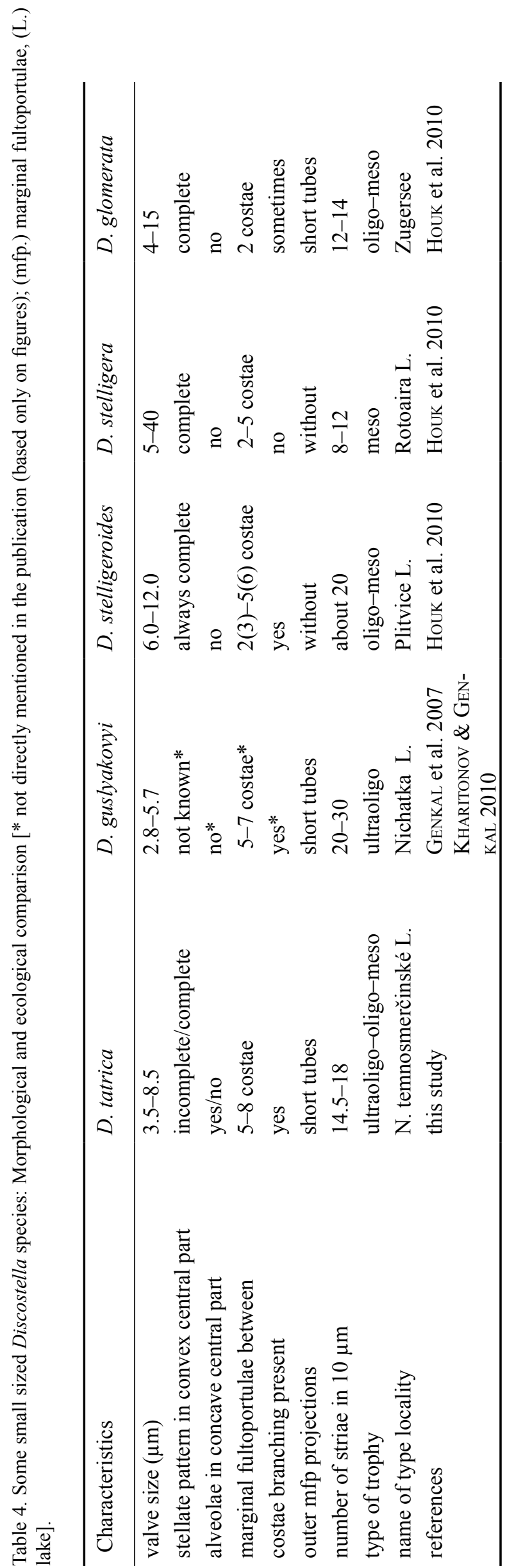

However, in contrast to $D$. stelligeroides, $D$. tatrica can have an incomplete stellate pattern in the convex central parts and can possess alveoli in the concave central parts. D. tatrica differs from D. guslyakowyi in having alveolae in the convex central parts and often in the concave central parts, too, whereas D. guslyakovyi, as it is depicted in the original description (GenKAL et al. 2007), has no structure in the valve central part, even though this fact is not explicitly mentioned in that report. Furthermore, under LM D. stelligera var. tenuis (Hustedt) Houk et KleE seems to be similar to D. tatrica (see Houk et al. 2010, table 307, figs 1-7); however, no investigation of this taxon was made in SEM, so its exact taxonomic position and relationship to $D$. tatrica is not yet clear.

Several authors of previous studies of Tatra Mountain phytoplankton identified D. tatrica as Cyclotella stelligera Cleve et Grunow (ŠTEFKová 2006) or Cyclotella stelligera var. glomerata (BACHM.) HaWorth et Hurley (Houk 1989). Generally, identification of small centric diatoms is quite difficult, particularly under LM. Only SEM could reveal the detailed valve morphology: Fultoportulae and rimoportulae are located between costae in the genus Discostella, while these structures are situated on the marginal costae in the genus Cyclotella. That is why Cyclotella sp. has been often recorded in floristic papers. Some references to the Tatra Mountain phytoplankton could therefore actually be referring to $D$. tatrica (e.g. DARGOCKÁ et al. 1997). A morphological and ecological comparison of some small Discostella species is summarised in Table 4.

A large number of the Tatra Mountain lakes were affected by acid deposition which peaked in the 1980s (STUCHLík et al. 1985; Koṕ́Č́EK et al. 2004). Chemical recovery of some lakes from acidification started in the early 1990s (KOPÁČEK et al. 2004), but biological recovery has been delayed or has still not even started (SACHEROVÁ et al. 2006; ŠTEFKOVÁ 2009). Important changes of lake water quality are still in progress in the Tatra Mountains (KopÁČEK et al. 2006). The current distribution and biomass of diatoms in the plankton (this study) as well in the epipelon (ŠTEFKOVÁ 2006) probably reflects these ongoing changes. Discostella tatrica was not accompanied by the wide-spread and rather acid-tolerant Tabellaria flocculosa. One explanation for the Discostella distribution in the Tatras is probably its requirement for neutral $\mathrm{pH}$ (higher levels of ANC). Indeed, several previous studies have 
demonstrated the absence of centric diatoms in acid lakes and subsequent re-colonization after lake water $\mathrm{pH}$ increases (HÖRNSTRÖM et al. 1993; HöRNSTRÖM 1999). Therefore, centric diatoms could indicate the recovery of lakes from acidification.

According to the type of the catchment vegetation, the Tatra lakes have been divided into four main groups: forest, meadow, meadowrocky and rocky lakes (KOPÁČEK et al. 2006). The catchment vegetation type of lakes inhabited by $D$. tatrica was in most cases meadow-rocky. The majority of these lakes were ultra- to oligotrophic according to a classification of phytoplankton biovolume (WeTzeL 2001). The highest biovolume of Discostella tatrica was found in the mesotrophic Przedni Staw Polski Lake (Table 2). Tolerance to different levels of nutrients was also observed for the similarly sized diatom $D$. pseudostelligera (Hustedt) Houk et Klee (Cremer 2006; TANAKa 2007), whereas D. stelligeroides was only found in oligotrophic to mesotrophic lakes (Houk et al. 2010). D. guslyakovyi was found in an ultraoligotrophic lake (KHARITONOv \& GENKAL 2010). In addition, it has been shown that zooplankton, UV-radiation and temperature can play an important role in determining the biomass of another diatom in alpine lakes, D. stelligera Houk et Klee (Williamson et al. 2010).

Here, we describe a new diatom species, Discostella tatrica, from mountain lakes in the Tatras (Slovakia/Poland). During identification of diatoms, many characteristics should be taken into account, and detailed knowledge of similar species is necessary. We compared the valve morphology, ultrastructure and ecology of Discostella tatrica with other similar Discostella taxa. Further research into the phytoplankton diversity of remote alpine lakes in the Tatras may yet lead to the discovery of other new species. Moreover, comprehensive phylogenetic studies of Discostella species is needed to better elucidate their relationships.

\section{Acknowledgements}

We would like to thank to Dr. Lubomír Kováčik, Faculty of Natural Sciences, Comenius University in Bratislava, Slovakia, for providing the bottom sediment material and physico-chemical parameters from the lakes Nižné and Vyšné Temnosmrečinské pleso. We are grateful to Dr. Petr Marvan (Botanical Institute, Czech Academy of Sciences, Třeboň, now retired) for making the Latin diagnosis. The samples were collected in the framework of the project EURO-LIMPACS (GOCECT-2003-505540), the investigation of diatoms by SEM and TEM was supported by MŠMT ČR (projects MSM0021620828 and by the institutional long-term research plan No. AV0Z60050516, funded by the Academy of Sciences of the Czech Republic.

\section{References}

Cremer, H. (2006): The planktonic diatom flora of a high arctic lake in East Greenland. - Nord. J. Bot. 24: 235-244.

DargockÁ, J.; Kneslová, P. \& Stuchlík, E. (1997): Fytoplanktón niektorých rôzne acidifikovaných plies Vysokých Tater.- Štúdie o TANAPu 2: 41-62.

Hildebrandt, H.; Durselen, C.D.; Kirschtel, D.; Pollingher, U. \& Zohary, T. (1999): Biovolume calculation for pelagic and benthic microalgae. - J. Phycol. 35: 403-424.

Genkal, S.I.; Bondarenko, N.A. \& Popovskaya, G. I. (2007): New representative of the genus Discostella Houk \& Klee from the Eastern Baikal area (Russia). - International Journal on Algae 9: 359-364.

Hörnström, E.; Ekström, C.; Fröberg, E. \& Eк, J. (1993): Plankton and chemical-physical development in six Swedish West Coast lakes under acidic and limed conditions. - Can. J. Fish. Aqut. Sci. 50: 688-702.

HöRnströM, E. (1999): Long-term phytoplankton changes in acid and limed lakes in SW Sweden. - Hydrobiologia 394: 93-102.

Houk, V.(1989): Centrickérozsivky(Bacillariophyceae) tatranských ples. - In: Goliášová, K. (ed.): Abstrakty 5. zjazdu SBS pri SAV, T. Lomnica 1989. - p. 7, SAV, Bratislava.

Houk, V. \& KLEe, R. (2004): The stelligeroid taxa of the genus Cyclotella (Kutzing) Brebisson (Bacillariophyceae) and their transfer into the new genus Discostella gen. nov. - Diatom Research 19: 203-28.

Houk, V.; Klee, R. \& Tanaka, H. (2010): Atlas of freshwater centric diatoms with a brief key and descriptions, Part III., Stephanodiscaceae A, Cyclotella, Tertiarius, Discostella. - Fottea 10 (Supplement): 1-498.

Jung, S. W.; HAN , M. S. \& KI, J. S. (2010): Molecular genetic divergence of the centric diatom Cyclotella and Discostella (Bacillariophyceae) revealed by nuclear ribosomal DNA comparisons. - J. Appl. Phycol. 22: 319-329.

Kharitonov, V. G. \& Genkal, S. I. (2010): Centric diatom algae (Centrophyceae) of ultraoligotrophic lake Elgygytgyn and water bodies of its basin (Chukotka, Russia). - Inland water biology 3: 1-10. 
KopÁČek, J.; Hardekopf, D.; Majer, M.; PŠEnÁKovÁ, P.; Stuchlí, E. \& VeselÝ, J. (2004): Response of alpine lakes and soils to changes in acid deposition: the MAGIC model applied to the Tatra Mountain region, Slovakia-Poland. - J. Limnol. 63: 143-156.

KopÁČEK, J.; Stuchlík, E. \& Hardekopf, D. (2006): Chemical composition of the Tatra Mountain lakes: Recovery from acidification. - Biologia, Bratislava, 61(Suppl. 18): 21-23.

Krammer, K. \& Lange-Bertalot, H. (1986): Bacillariophyceae. 1 Teil: Naviculaceae. - In: EtTL, H.; Gerloff, J.; Heynig, H. \& Mollenhauer, D. (eds): Die Süsswasserflora von Mitteleuropa 2. - 876 pp., Gustav Fischer Verlag, Stuttgart.

PACL, J. (1973): Hydrológia Tatranského národného parku (The Hydrology of the Tatra National Park). - Zborník TANAP 15: 181-238.

SACherovÁ, V.; KrŠKovÁ, R.; STUChlík, E.; HořickÁ, Z.; Hudec, I. \& FotT, J. (2006): Long-term change of littoral Cladocera in the Tatra Mountain lakes through a major acidification event. - Biologia, Bratislava, 61(Suppl. 18): 109-119.

Straškrabová, V.; Callieri, C.; Carrillo, P.; CruzPizarro, L.; Fott, J.; Hartman, P.; MaceK, M.; Medina-SÁnchez, J. M.; Nedoma, J. \& Š ImeK, K. (1999): Investigations on pelagic food webs in mountain lakes - aims and methods. - J. Limnol. 58: 77-87.

Stuchlík, E.; Stuchlíková, Z.; FotT, J.; RůžIČKA, L. \& VRBA, J. (1985): Vliv kyselých srážek na vody na území Tatranského národního parku. Zborník TANAP 26: 173-212.

ŠTEFKovÁ, E. (2006): Epilithic diatoms of mountain lakes of the Tatra Mountains (Slovakia). Biologia, Bratislava, 61(Suppl.18): 101-108.

ŠtefKovÁ, E. (2009): Porovnanie spoločenstiev rozsievok tatranských plies $\mathrm{v}$ období před industrializáciou a $\mathrm{v}$ súčasnosti. - In: KröPfElovÁ, L. \& ŠulcovÁ, J. (eds): Sborník příspěvků 15. konference České limnologické společnosti a Slovenskej limnologickej spoločnosti, Třeboň, 22.-26. června 2009. pp. 259-262, Třeboň.

TANAKA, H. (2007): Taxonomic studies of the genera Cyclotella (Kützing) Brébisson, Discostella Houk \& Klee and Puncticulata Håkansson in the family Sephanodiscaceae Glezer \& Makarova (Bacillariophyta) in Japan. - In: Bibliotheca Diatomologica 53. - 205 pp., J. Cramer, Stuttgart, Berlin.

Ter BraAk, C. J. F. \& Šmilauer, P. (1998): CANOCO Reference Manual and User's Guide to Canoco for Windows. - 353 pp., Microcomputer Power. Ithaca, NY, US.

Tuji, A. \& Williams, D. M. (2006): The Identity of Cyclotella glomerata Bachmann and Discostella nipponica (Skvortzov) Tuji \& Willims comb. et stat. nov. (Bacillariophyceae) from Lake Kizaki, Japan. - Bull. Nat. Sci. Mus., Tokyo, Ser. B 32: $9-14$.

UtermöHL, H. (1931): Neue Wege in der quantitativen Erfassung des Planktons. - Verh. Int. Verein Limnol. 5: 567-596.

Wetzel, R. G. (2001): Limnology, Lake and Water Ecosystems. - 1006 pp., Academic Press, London.

Williamson, C. E.; Salm, C.; Cooke, S. L. \& Saros, J. E. (2010): How do UV radiation, temperature, and zooplankton influence the dynamics of alpine phytoplankton communities? - Hydrobiologia 648: 73-81.

(C) Czech Phycological Society (2012)

Received April 4, 2011

Accepted September 11, 2011 